\title{
THE USE OF PINEAPPLE FRUIT IN BATTING PROCESS ON THE CHEMICAL PROPERTIES OF SHEEPSKIN USING SHORFLOAT TANNING
}

\author{
Roselini Agustia Andini' ${ }^{1)}$, Mustakim ${ }^{2)}$, Imam Thohari ${ }^{2)}$ \\ 1) Magister Student of Faculty of Animal Science, Universitas Brawijaya, Jl. Veteran, Kota Malang, East \\ Java, Indonesia, 65145 \\ ${ }^{2)}$ Lecturer of Faculty of Animal Science, Universitas Brawijaya, Jl. Veteran, Kota Malang, East Java, \\ Indonesia, 65145 \\ *Corresponding Email: mustakimfptub@ub.ac.id
}

Submitted 13 January 2021; Accepted 26 November 2021

\begin{abstract}
Batting is the process of removing globular and non-collagen proteins. Bromelain can be found in all parts of the pineapple plant (Ananas comosus L.) with different amounts and properties. Bromelain can be used as a batting agent in the tanning process. The purpose of this study was to determine the effect of the bromelain enzyme concentration used during the protein removal process on the quality of sheepskin. This research used 30 sheets of sheepskin obtained from abattoir in Yogyakarta City and pineapple fruit's flesh. The experimental design used was a completely randomized design. The research uses different concentrations of pineapples fruit's flesh (T1 0,5\%, T2 1\%, T3 1,5\% and T4 2\% w/w) with feliderm (T0). Statistical analysis using one-way analysis of variance and in accordance with the statistical model. The results of this study showed in dissolved protein content was T0 0.83\%, T1 0.77\%, T2 $0.68 \%$, T3 $0.82 \%$ and T4 $0.85 \%$, protein content of batting skin was T0 19.17\%, T1 17.90\%, T2 18.37\%, T3 21.35\% and T4 21.50\%, protein content of leather was T0 59.69\%, T1 59.27\%, T2 60.34\%, T3 61.59\% and T4 63.25\%, fat content was T0 15.31\%, T1 14.61\%, T2 15.19\%, T3 15.36\% and T4 16.25\%, chromium content was T0 2.60\%, T1 2.67\%, T2 2.78\%, T3 2.82\% and $\mathrm{T} 43.00 \%$ and shrinkage temperature was $\mathrm{T} 092.33^{\circ} \mathrm{C}, \mathrm{T} 195.67^{\circ} \mathrm{C}, \mathrm{T} 293.67^{\circ} \mathrm{C}, \mathrm{T} 3$ $96.33^{\circ} \mathrm{C}$ and $\mathrm{T} 497.33^{\circ} \mathrm{C}$. The results for pineapple juice showed potency to be used as batting agent for sheepskin. The minimum amount of pineapple juice added for batting the sheepskin is $1 \%(\mathrm{w} / \mathrm{w})$.
\end{abstract}

Keyword: Batting; bromelain; sheepskin. 


\section{INTRODUCTION}

The skin is the outermost structure of humans, animals and plants. The skin that can be used in the manufacture of products is finished leather, which is leather that has been tanned or processed using chemicals with a certain dose and time calculation. Leather has unique properties and characteristics that are not shared by other materials. One piece of skin may have different properties, so the knowledge to determine the quality of the skin is necessary. Kholifah et al., (2014) state that leather tanning is a process to convert raw hides and skins into tanned leather. Raw skin rots easily when dry, hard and stiff, while tanned skin has the opposite property. Tanning is intended to obtain skin that is not easily damaged and durable.

Batting is the process of eroding globular proteins including unsabbed fat and breaking the polypeptide chains in the skin tissue collagen proteins with the aim of opening up collagen fibers so that it can easily bind to the tanning material. Batting agents that are commonly used are oropon and feliderm and most of the currently used batting agents are imported materials. To reduce the amount of imported batting materials, other alternative materials were sought using protease enzyme activity. Protease enzymes come from plants (papain, bromelain, and ficin) and from Rhizopus sp. (Setiawan et al., 2015).

Bromelain can be found in all parts of the pineapple plant with different amounts and properties. Bromelain can be used as a protein eroding agent in the tanning process. Bromelain is used in the leather industry for pre-tanning, softens skin and removes protein, improves the coloring properties of protein fibers and breaks down all or part of the soluble protein fibers from silk and wool (Ketnawa et al., 2011). This study aims to determine the effect of the bromelain enzyme concentration used during the protein removal process on the quality of the leather made from sheepskin after shortfloat tanning based on its chemical properties.

\section{MATERIALS AND METHODS}

\section{Location and Time}

This research was conducted in November 2020 located at the Yogyakarta Center for leather, rubber and plastics.

\section{Research Materials}

The materials used for this research were 30 sheets of sheepskin from slaughterhouse at Yogyakarta city and pineapple fruits.

\section{Pineapple Pulp Preparation}

The pineapple fruit was cleaned and peeled to get the flesh. The pineapple flesh was then divided into 4 parts, each part was crushed using a blender until it became pulp. The pineapple pulp was then filtered so that the water and the solids got separated. The solid part was used in the batting process.

\section{Batting Process}

The batting process is very important to facilitate the process of removing noncollagen compounds (especially protein and fat). Batting is the process of eroding globular proteins and glycogen including fat. Batting agents commonly used are oropon, plant proteases (papain and bromelain) and Rhizopus sp. The batting process in this study was carried out by immersing the sheepskin into a rotating
*Corresponding author:

Mustakim

Email: mustakimfptub@ub.ac.id

Lecturer of Faculty of Animal Science, Universitas

Brawijaya, Jl. Veteran, Kota Malang, East Java, Indonesia, 65145
How to cite:

Andini, R. A., Mustakim., \& Thohari, I. (2021). The Use of Pineapple Fruit in Batting Process on the Chemical Properties of Sheepskin Using Shorfloat Tanning. Jurnal Ilmu dan Teknologi Hasil Ternak (JITEK), 16 (3), 166-173 
drum for $1 \mathrm{~h}$ according to the treatment group (Table 1). After the drum was stopped, the water was removed and the testing for the success rate of the batting process was performed using a thumb test or permeability test.

Table 1. Formulation of batting process using a completely randomized design with 5 treatments and 3 replications

\begin{tabular}{lccccc}
\hline \multirow{2}{*}{ Material } & \multicolumn{5}{c}{ Treatment } \\
\cline { 2 - 6 } & T0 & T1 & T2 & T3 & T4 \\
\hline Sheepskin (Sheets) & 6 & 6 & 6 & 6 & 6 \\
Feliderm (\% w/w) & 1 & - & - & - & - \\
Pineapple Juice (\% w/w) & - & 0.5 & 1 & 1.5 & 2 \\
Water (\% w/w) & 100 & 100 & 100 & 100 & 100 \\
\hline
\end{tabular}

\section{Dissolved Protein Content (Sudarmadji, 1989)}

Dissolved protein levels were analyzed by using the batting waste to indicate the number of substances the skin does not required which can be eroded by the enzyme. Dissolved protein content showed unnecessarily percentage.

\section{Protein Content Skin Post-batting (Sudarmadji, 1989)}

Protein content in batting skin was analyzed by preparing $100 \mathrm{~g}$ of skins sample and place them in the petri dish then using Kjeldahl method to test the percentage of protein collagen after batting process.

\section{Protein Content of Leather (Sudarmadji, 1989)}

Protein levels total finishing was analyzed by using Kjeldahl method to test the percentage of protein collagen after finishing.

\section{Fat Content (SNI. 0234-1989)}

A total of $10.0 \mathrm{~mL}$ spent degreasing liquors were centrifuged at $3,500 \mathrm{rpm}$ for $10 \mathrm{~min}$. Afterward, $5.0 \mathrm{~mL}$ supernatant and $5.0 \mathrm{~mL} \mathrm{HCl}(6.0 \mathrm{~mol} / \mathrm{L})$ were placed into $25 \mathrm{~mL}$ tube. The mixture was stirred for $30 \mathrm{~min}$ and extracted with $4 \mathrm{~mL}$ isooctane. The fatty acids in the extracts were determined according to the method of copper soap spectrophotometry.

\section{Chromium Content (SNI. 0234-1989)}

Melted skin ash at a temperature of $600-700^{\circ} \mathrm{C}$, with a mixture of $2 \mathrm{~g}$ of $\mathrm{Na}_{2} \mathrm{CO}_{3}$ and $\mathrm{K}_{2} \mathrm{CO}_{3}$, each, the chromoxide will become chromate salt. cooled, then the solution is checked for chromium by yodometrics.

\section{Shrinkage Temperature (Nuraini, 2019)}

Skin samples from the tanning and retanning process with a skin thickness of $0.7 \mathrm{~mm}$. The skin sample was cut with a length of $50 \mathrm{~mm}$ and a width of $5 \mathrm{~mm}$. The top and bottom were given a hole about $5 \mathrm{~mm}$ from the end with a hole pin. The skin sample was put into a $1000 \mathrm{ml}$ beaker containing distilled water. After being clamped on the hook, the beaker containing the distilled water is lowered. Turn the hand wheel clockwise until it is about $3 \mathrm{~cm}$ above the bottom of the beaker. Turn on the power setting temperature control at $100^{\circ} \mathrm{C}$ then press the power button. Observe the movement of the needle that shows the shrinkage rate of the sample where each scale represents a shrinkage of $0.3 \%$ of the sample and the shrinkage temperature movement.

\section{Statistical Analysis}

All the data results were analyzed by using ANOVA test with a significant level of 5\% and if there was a significant effect then continued with Duncan Multiple Range Test. 


\section{RESULTS AND DISCUSSION}

\section{Dissolved protein content}

The results of the study of protein levels before batting is average $0.83 \%$ in $\mathrm{T} 0,0.77 \%$ in $\mathrm{T} 1,0.68 \%$ in $\mathrm{T} 2,0.82 \%$ in $\mathrm{T} 3$ and $0,85 \%$ in $\mathrm{T} 4$. The difference in batting results is affected by the speed of tanning drum and batting time. According to Wilson (1978) substance chemicals that compose the skin among others is 65\% water, $33 \%$ protein, $0,5 \%$ minerals and $2-30 \%$ fat. Chemical's composition doesn't constant because it depends on the type of the skin.

$\mathrm{T} 2$ treatment be the lowest compared to the others because drum that is used has a speed $8 \mathrm{rpm}$ that affecting the batting less maximal but the batting process still succeed because the batting principle minimal $0,5 \%$ and maximum $2 \%$ in giving batting agent. T0, T3 and T4 treatment showed results that were not too different because it's both used feliderm as batting and used a tanning drum with a 13-rpm drum. According to Santika et al. (2014) the increase amounts of enzymes during the batting process is directly to dissolved protein content. Increasing the number of enzymes will increase the amount of dissolved protein in the tannery waste. Dissolved protein levels in the tannery waste indicate the number of substances the skin is not required which can be eroded by the enzyme. During the batting process, noncollagen protein will be lost and chromium easier to bind with the collagen. The batting process is really important during tanning process. Batting process aims to break down the components of the skin in specific. In general, the target in this process is noncollagen protein. Protein will be broken down by the protease enzyme. The enzyme will break the chains of peptides and form many smaller molecules, so it's easier to remove by just rinsing. (Covington, 2009).

Table 2. Research results before batting (protein levels) and batting (total protein levels, total finishing protein levels and fat levels) on sheepskins in shortfloat tanning based on chemical properties.

\begin{tabular}{cccc}
\hline \multirow{2}{*}{ Treatment } & \multicolumn{3}{c}{ Variable } \\
\cline { 2 - 4 } & $\begin{array}{c}\text { Dissolved protein } \\
\text { content }(\%)\end{array}$ & $\begin{array}{c}\text { Protein content of batting } \\
\text { skin }(\%)\end{array}$ & $\begin{array}{c}\text { Protein content of } \\
\text { leather }(\%)\end{array}$ \\
\hline T0 & $0.83 \pm 0.005^{\mathrm{b}}$ & $19.17 \pm 0.33^{\mathrm{b}}$ & $59.69 \pm 0.43^{\mathrm{a}}$ \\
T1 & $0.77 \pm 0.016^{\mathrm{a}}$ & $17.90 \pm 0.70^{\mathrm{a}}$ & $59.27 \pm 1.03^{\mathrm{a}}$ \\
T2 & $0.68 \pm 0.053^{\mathrm{a}}$ & $18.37 \pm 0.38^{\mathrm{ab}}$ & $60.34 \pm 0.02^{\mathrm{a}}$ \\
T3 & $0.82 \pm 0.076^{\mathrm{b}}$ & $21.35 \pm 0.48^{\mathrm{c}}$ & $61.59 \pm 0.40^{\mathrm{ab}}$ \\
T4 & $0.85 \pm 0.041^{\mathrm{b}}$ & $21.50 \pm 0.31^{\mathrm{c}}$ & $63.25 \pm 0.40^{\mathrm{c}}$ \\
\hline
\end{tabular}

Remakes: *Different superscripts from the same column show very significant differences (P $<0.01)$ in the dissolved protein content, protein content of batting skin and protein content of leather.

\section{Protein Content of Batting Skin}

The results of the research on protein content after batting obtained an average of $19,17 \%$ in $\mathrm{T} 0,17,90 \%$ in $\mathrm{T} 1$, $18,37 \%$ in $\mathrm{T} 2,21,35 \%$ in $\mathrm{T} 3$ and $21.50 \%$ in $\mathrm{T} 4$. Differences result in batting influenced by the concentration of the enzyme, duration of the batting and speed of the drum used. It is indicating that the skin with batting using pineapple juice can provide the results of batting as same as using feliderm.
T4 treatment be the most high compared to the others because the pineapple fruit are used as much as $2 \%$, the pineapple fruit has high protease activity so it capable to eroding globular proteins that are in the skin. Treatment of T1, T2, T3 shows the results that are not too much different because it's using same pineapple as batting agent. According to Syafie et al., (2013) Rhizopus has proteolytic activity of $392,89 \mu / \mathrm{mg}$ protein. According to Hayati 
et al., (2103) the protease activity in all treatment concentrations batting agent capable to eroding non-collagen protein that inhibits the penetration of tanning materials to the tissue skin. The batting process can affect the quality of the skin produced. According to Santika (2014) the longer the batting process can reduce the tensile strength. It is because the enzyme is not only hydrolyzed the non-collagen protein which can bind to the tanning material, so the tensile strength will further decrease as increasing the batting time. More and more protein skins are hydrolyzed causing the skin fibers to break down and can widen the weave of the skin fibers. The higher the collagen protein content, which is able to bind to the tanning material, the higher the tensile strength. On the other hand, the lack of protein that can be degraded in the protein removal process can inhibit the entry of the tanner into the skin fibers so that a small amount of tanning material can enter. In addition, the lack of a protein degradation process can also inhibit the entry of oil, resulting in a leather with low elongation.

\section{Protein Content of Leather}

The results of the research on total protein levels after batting obtained an average of $59.69 \%$ in $\mathrm{T} 0,59.27 \%$ in $\mathrm{T} 1$, $60.08 \%$ in $\mathrm{T} 2,61.59 \%$ in $\mathrm{T} 3$ and $63.25 \%$ in T4. The difference in the results of the batting was influenced by the enzyme concentration and also the batting time. It is indicating that the skin with batting using pineapple can provide the results of batting the same by using palkobat.

Table 3. Research results fat content, chromium content and shrinkage temperature on sheepskins in shortfloat tanning.

\begin{tabular}{cccc}
\hline & \multicolumn{3}{c}{ Variable } \\
\cline { 2 - 4 } Treatment & $\begin{array}{c}\text { Fat Content } \\
(\%)\end{array}$ & $\begin{array}{c}\text { Chromium content } \\
(\%)\end{array}$ & $\begin{array}{c}\text { Shrinkage Temperature } \\
\left({ }^{\circ} \mathrm{C}\right)\end{array}$ \\
\hline T0 & $15.31 \pm 0.13^{\mathrm{b}}$ & $2.60 \pm 0.15^{\mathrm{a}}$ & $92.33 \pm 2.08^{\mathrm{a}}$ \\
T1 & $14.61 \pm 0.04^{\mathrm{a}}$ & $2.67 \pm 0.06^{\mathrm{ab}}$ & $95.67 \pm 0.57^{\mathrm{bc}}$ \\
T2 & $15.19 \pm 0.28^{\mathrm{b}}$ & $2.78 \pm 0.23^{\mathrm{ab}}$ & $93.67 \pm 0.57^{\mathrm{ab}}$ \\
T3 & $15.36 \pm 0.10^{\mathrm{b}}$ & $2.82 \pm 0.03^{\mathrm{ab}}$ & $96.33 \pm 0.57^{\mathrm{c}}$ \\
T4 & $16.25 \pm 0.08^{\mathrm{c}}$ & $3.00 \pm 0.21^{\mathrm{b}}$ & $97.33 \pm 0.57^{\mathrm{c}}$ \\
\hline
\end{tabular}

Remakes: *Different superscripts from the same column show very significant differences (P $<0.01$ ) in the fat content, chromium content, and shrinkage temperature.

T1 treatment be the lowest compared to the others because pineapple fruits are used as much as $0.5 \%$ but still able to erode protein. Pineapple fruit has a protease activity so it can erode globular protein in the skin. T1, T2, T3 and T4 treatment show non-significant effect cause using pineapple as batting. Batting agent can be a protease enzyme. Protease enzyme are added to break down non-collagen proteins so that no needed protein such as elastin, globular and epidermal proteins lost (Farid et al., 2015). The ability of the protease enzyme to hydrolyze protein and remove parts of the skin that are not needed in the tanning process and resulting opening of the fibers in the collagen so collagen will bind to the tanning material which in turn will increase the physical strength of the skin (Santika et al., 2014).

\section{Fat Content}

The fat levels after batting obtained an average of $15.31 \%$ in $\mathrm{T} 0,14.61 \%$ in $\mathrm{T} 1,15.19 \%$ in $\mathrm{T} 2,15.36 \%$ in $\mathrm{T} 3$ and $16.25 \%$ in T4. The differences result on the fat levels is affected by the speed of the drum tanning and batting duration also high fat in the tanned sheepskin caused by several factors is because degreasing not maximal and fat liquoring when tanning process. Dewi et al., (2016) states that the value of fat levels is proportional to the amount of oil used if too much fat content in skin indicates 
that skin is too weak and easily fester, causing blemishes on the skin, whereas if the fat content is too low it means that the skin dries quickly and prone to crack and break when exposed to heat. Fat levels had an important role in the outcome of tanning process because the amount of oil that contained in the skin will affect the quality of the tanned skin, fat is a part that is cannot separated by the skin and give effect to the tanning process. The perfect degreasing will help in the process of penetrating tanning material into the skin more smoothly and is not hampered by fat lumps on the skin. (Juliyarsi et al., 2013).

The tanning process has limitations on the level of fat or oil. The content of fat skin is less than $3 \%$ will be difficult to moistened and leather result a bit stiff. High fat content $(>8 \%)$ the process of tanning will not perfect and can inhibit the penetration tanner into the skins. In addition, the tanned skin will look like blemishes if adding more materials like paint (Yeni et al., 2016). Fat liquoring is carried out in a predetermined amount in accordance with the objectives to be achieved such as wallet or belt that does not require much softness so that it is adjusted to the increase in the amount of oil used that tend to be lower, very different with the purpose of the product. Material made to jacket or bag then elongation that needed getting higher by the amount of oil that is added which also will impact on the content of fat at the time of the tested tanning skin.

\section{Chromium Content}

The chromium content in the tanned sheep skin indicates the amount of chromium that can be bound by skin collagen. The batting process can remove unnecessary non-collagen skin components so that it can make it easier for chrome to bind to collagen. This is based on Mustika (2001), the skin fibers that have been opened and the cleansing of the skin from noncollagen substances cause the tanning agent to easily enter the skin fibers, so that the tanning material easily enters the skin fiber tissue. The bonds formed between the chromium and collagen proteins will change the nature of the raw skin to become more resistant to physical and chemical influences.

The results of the analysis of variance showed that the different time-playing treatments had a very significant effect $(\mathrm{P}$ $<0.01$ ) on the chromium content of the leather. The highest chromium content was obtained at $\mathrm{P} 4$ is $3.00 \pm 0.21 \%$ with pineapple juice of $2 \%$, this happened because the longer batting time caused the skin's collagen structure to open up, making it easier for tanning substances to enter and bind to collagen. The highest chromium content result was then obtained at $\mathrm{P} 3$ is 2.82 $\pm 0.03 \%$ with pineapple juice of $1.5 \%$. The lowest chromium content of the tanned sheep skin was obtained at P0 is $2.60 \pm$ $0.15 \%$ using feliderm 1\%, P1 of $2.67 \pm$ $0.06 \%$ is $0.5 \%$ pineapple juice, and $\mathrm{P} 2$ of $2.78 \pm 0.23 \%$ with $1 \%$ pineapple juice.

According to Mustakim et al. (2007) the increase in tanneries can bind to collagen determines the efficiency of tanning. If the high concentration of chromium which can be bound to collagen fibers causes an increase in the collagen reaction with chromium, vice versa, at low concentrations, it will reduce the bond between chrome and skin collagen. The increase in the concentration of the chromium tanning material in the tanning will increase the coordination of the chromium into the carboxyl group of the skin protein which results in the formation of a cross link between the chrome tanner and the polypeptide chain so that the protein becomes stable. The stability of the protein can determine the physical strength of the leather produced.

\section{Shrinkage Temperature}

The temperature obtained with the highest wrinkle temperature was $97.33^{\circ} \mathrm{C}$ by P4 with pineapple juice $2 \%$. The high temperature of the wrinkle is influenced by the binding of the skin proteins with the tanner. The penetration of the tanner causes the stability of the skin's protein against heat 
to increase. This causes the skin to have a higher wrinkle temperature. The reaction between chromium and skin collagen will increase skin stability due to the crosslinking that occurs, so that the skin structures that were originally separated become joined together to become a stronger structure (Hidayati et al., 2015).

The next highest temperature was treatment $\mathrm{P} 4$ of $97.33^{\circ} \mathrm{C}$ with pineapple juice $2 \%$ while the lowest wrinkle temperature was in treatment $\mathrm{P} 2$ of $93.67^{\circ} \mathrm{C}$ with pineapple juice $1 \%$ and treatment $\mathrm{P} 1$ of $95.67^{\circ} \mathrm{C}$ with pineapple juice $0.5 \%$. One of the standards for leather quality in SNI requires that the leather produced by the tanning industry be "ripe". To find out whether the tanned skin is "cooked" or not, it is necessary to test the skin shrinkage temperature. The skin shrinkage temperature is the temperature reached when the skin shrinks a maximum of $0.3 \%$ of the initial length, if the skin is slowly heated in a heating medium. Heating was carried out at a rate of $2^{\circ} \mathrm{C} / \mathrm{min}$ and the shrinkage temperature was recorded when the skin was seen to shrink. The shrinkage temperature needs to be known, especially for garment skins that require washing or ironing so that the washing or ironing process can be carried out at temperatures below the shrinkage temperature to avoid skin damage (Syaiful et al., 2016).

The overall results with the addition of pineapple fruit produce values above $90^{\circ} \mathrm{C}$, which is the lowest in $\mathrm{P} 2$ treatment with a value of $93.67^{\circ} \mathrm{C}$ which has shown a good value where the higher the wrinkle temperature obtained will indicate the skin will be stronger in resisting physical disturbances. especially heat, according to Setiawan et al (2015) stated that shrinkage temperature is closely related to skin maturity, the more skin fibers that bind to the tanning material, the higher the maturity of the resulting skin so that the wrinkle temperature is higher. The higher the skin wrinkle temperature, the better the product quality because the skin's resistance to heat (hydrothermal) is getting higher. Leather products that have a wrinkle temperature greater than $70^{\circ} \mathrm{C}$ will last longer because they have higher heat resistance (hydrothermal).

\section{CONCLUSIONS}

The results for pineapple pulp as the source of bromelain showed potency to be used as batting agent for sheepskin. The minimum amount of pineapple juice added for batting the sheepskin is $1 \%(\mathrm{w} / \mathrm{w})$.

\section{REFERENCES}

Covington, T. (2009). Tanning Chemistry. The Science of Leather. In International Conference Globalization, Innovation and Development. Trends and Prospects (G.I.D.T.P.) (Vol. 10).

Dewi, G. U., Ibrahim, R., \& Wijayanti, I. (2017). The effect of using different concentration of sulfited fish oil on the softness and quality of formalin tanned stingray. Saintek Perikanan: Indonesian Journal of Fisheries Science and Technology, 12(1), 2429. https://doi.org/10.14710/ijfst.12.1. 24-29

Farid, J., Riyadi, P., \& Amalia, U. (2015). Karateristik kulit samak ikan nila (Oreochromis niloticus) dengan penambahan batting agent alami dari pankreas sapi. Jurnal Saintek Perikanan, 10(2), 80-83.

Hayati, R. N., Latif, S., \& Amir, H. (2013). Kajian pengaruh konsentrasi Rhizopus sp. sebagai agen pengikis protein terhadap mutu kulit ikan gurami tersamak. Jurnal Teknosains, 2(2), 23-28. https://doi.org/10.22146/ teknosains.6003

Hidayati, A., Putut, H., \& Laras, R. (2015). Pengaruh batting agent dari ragi tempe (Rhizopus Oligosphorus) terhadap kualitas kulit ikan nila (Oreochromis Niloticus) samak. Jurnal Saintek Perikanan, 11(1), 26-33.

Juliyarsi, I., Novia, D., \& Helson, J. (2013). Kajian penambahan gambir sebagai 
bahan penyamak nabati terhadap mutu kimiawi kulit kambing. Jurnal Peternakan Indonesia (Indonesian Journal of Animal Science), 15(1), 35-45. https://doi.org/10.25077/jpi. 15.1.35-45.2013

Ketnawa, S., Chaiwut, P., \& Rawdkuen, S. (2011). Extraction of bromelain from pineapple peels. Food Science and Technology International, 17(4), 395402. https://doi.org/10.1177/1082013 210387817

Kholifah, N., Darmanto, Y., \& Wijayanti, I. (2014). Perbedaan konsentrasi mimosa pada proses penyamakan terhadap kualitas fisik dan kimia ikan nila (Oreochromis Niloticus). Jurnal Pengolahan Dan Bioteknologi Hasil Perikanan, 3(4), 113-118.

Mustakim, Widati, A., \& Lita, P. (2007). Tingkat presentasi tannin pada kulit kelinci samak berbulu terhadap kekuatan jahit, kekuatan sobek dan kelemasan. Jurnal Ilmu Dan Teknologi Hasil Ternak, 2(1), 26-34.

Mustika, D. (2001). Kualitas Kimia dan Organoleptik Kulit Biawak Jadi Asal Awet Kering dengan Berbagai Jenis dan Konsentrasi Bahan Bating. Institut Pertanian Bogor.

Nuraini, E. (2019). Shrinkage temperature tester gt kc-23 sebagai alat uji suhu kerut kulit kambing samak aldehid. Integrated Lab Journal, 7(1), 70-74.

Prayitno. (2014). Research for producing green garment leather by using vegetable tanning agent. Prosiding Seminar Nasional Kulit, Karet, Dan Plastik Ke-3 Yogyakarta, 67-83.

Santika, F., Riyadi, P., \& Anggo, A. (2014). Pengaruh lama perendaman dengan enzim papain pada proses batting terhadap kualitas kulit ikan nila (Oreochromis niloticus) samak. Jurnal Pengolahan Dan Bioteknologi Hasil Perikanan, 4(1), 15-20.

Sudarmadji, S., Haryono, B., \& Suhardi. (1989). Analisa Bahan Makanan dan Pertanian (1st ed.). Liberty.

Syafie, Y., Triatmojo, S., \& Pratiwiningrum, A. (2013). Penggunaan protease aspergillus sp. dan rhizopus sp. dengan konsentrasi yang berbeda dalam tahapan unhairing terhadap kualitas fisik dan limbah cair pada penyamakan kulit domba. Buletin Peternakan, 37(3), 133-145. https:// doi.org/10.21059/buletinpeternak.v37 i3.3092

Syaiful, H., Wahyu, P., \& Tri, R. S. (2016). Rekayasa Alat Uji Suhu Kerut Kulit Tersamak Sistem Digital. Prosiding Seminar Nasional Kulit, Karet Dan Plastik Ke-5.

Widowati, T. P., Suwarastuti, A., \& Budi P, A. (2003). Pengaruh penggunaan pankreas sapi dan dua jenis bahan penyamak terhadap kualitas fisik kulit skrotum kambing. Majalah Kulit, Karet, Dan Plastik, 19(1), 124-132. https://doi.org/10.20543/mkkp.v19i1. 246

Wilson, H. R. (1978). The Practice of Bating. In In: The Chemistry and Technology of Leather (1st ed.). Reinhold Publishing Corporation.

Yeni, G., Syafruddin, D., \& Kasim, A. (2016). Pengujian kemampuan daya samak cube black dan limbah cair gambir terhadap mutu kulit tersamak. Jurnal Litbang Industri, 6(1), 73-82. https://doi.org/10.24960/jli.v6i1.1124 .73-82 